\title{
ANTIFUNGAL POTENTIAL OF CASHEW NUT SHELL LIQUID IN THE CONTROL OF PLANT PATHOGENS
}

\author{
POTENCIAL ANTIFÚNGICO DO LÍQUIDO DA CASTANHA DE CAJU NO \\ CONTROLE DE FITOPATÓGENOS
}

\author{
Nayara Zielasko Trombini GARCIA ${ }^{1}$; Giselle Feliciani BARBOSA ${ }^{2}$; Rosemary MATIAS ${ }^{3}$; \\ Denise Renata PEDRINHO ${ }^{3}$; José Antonio Maior BONO ${ }^{3}$; Daiane MARTINI ${ }^{4}$ \\ 1. Doctoral student, Anhanguera Uniderp University, Campo Grande, MS, Brazil, nayztg@ hotmail.com; 2.Ph.D Professor, State \\ University of Mato Grosso do Sul (UEMS), Cassilândia, MS, Brazil; 3. Ph.D Professor, Anhanguera Uniderp University, Campo \\ Grande, MS, Brazil; 4. Serviço Nacional de Aprendizagem Industrial/SENAI - Laboratory of Food Analysis/LANAL, Chapecó, SC, \\ Brazil.
}

\begin{abstract}
Extracted from the fruit of Anacardium occidentale L., Cashew Nut Shell Liquid (CNSL) is a phenolic lipid that has potential biological use. Conventional pesticides are increasingly being replaced by natural products because of the impact that their mismanagement can have on human health and the environment. The objective of this work was to evaluate the fungicidal potential effect of CNSL on the fungi Colletotrichum gloesporioides and Lasiodiplodia theobromae, in particular its use in reducing negative impacts on fruit production. Chemical and physical tests were conducted to determine features of the sample, such as $\mathrm{pH}$, electrical conductivity and solubility, and to measure its anacardic acid content. In vitro and in vivo tests were also conducted to evaluate the inhibition of mycelial growth on papaya fruit, the identification of volatile components and the inhibition of spore production. CNSL had the highest fungicidal potential for both fungi in vitro at a concentration of $320 \mu \mathrm{g} \mathrm{mL}^{-1}$, and the same concentration was also maximal for sporulation inhibition in both fungi. In the in vivo tests the protective effect of CNSL was higher for C. gloesporioides fungus, whereas its curative effect was higher for $L$. theobromae. It was found that the substance with fungicidal potential was non-volatile and that the presence of the pathogens altered the chemical properties of the fruit.
\end{abstract}

KEYWORDS: Alternative control. Anacardic acid. Carica papaya L.

\section{INTRODUCTION}

Because the use of pesticides in agriculture increases yield and maximizes the marketcompetitive characteristics of fruit, the practice is commonly adopted by producers. However, their use often has negative effects (HERREROHERNÁNDEZ, 2013).

A number of species which contribute to environmental homeostasis have been undergoing high selective pressures. Animals such as bees, fish, amphibians, bats and birds are experiencing many parasite outbreaks and suffering from immune suppression arising from pesticide mismanagement (MANSON, 2013).

For humans, the negative consequences are alarming regardless of whether contamination occurs directly, through oral consumption or via the skin, or indirectly, as a result of residues in food and water. Common effects are: (1) skin irritation, (2) intoxication, (3) damage to the reproductive system, (4) pre and postnatal mutagenesis and (5) carcinogenesis (HALLENBECK; CUNNINGHAMBURNS, 2012).

Research entities have been looking into ways of replacing these chemical compounds with less harmful natural products. Cashew Nut Shell
Liquid (CNSL), a by-product of the processing of cashew nuts, is widely considered a renewable, natural and low cost raw material. Its composition is determined by the mode of extraction, because anacardic acid, its primary substance, is a labile molecule which forms three new substances during the decarboxylation process: cardol, cardanol and polymeric material, all of which are made up of phenolic compounds with demonstrated potential for biological application (MAIA et al., 2015).

Fruit crops are highly susceptible to pathogen infestation. The plant pathogens $C$. gloeosporioides and L. theobromae are fungi with a wide range of hosts. They cause significant pre and post-harvest losses, which can cumulatively reach up to $50 \%$ of total yield (BAUTISTA-BANOS, 2013).

This study aimed to establish the potential of CNSL to control the spread of $C$. gloesporioides and L. theobromae (BAUTISTA-BANOS, 2014).

\section{MATERIAL AND METHODS}

The CNSL used in these experiments was extracted from Anacardium occidentale (cashew) flesh, provided by Resibras Company ${ }^{\circledR}$, located in São Paulo, SP. 
The sample had the following characteristics: $\mathrm{pH}$ of $6.5 \pm 0.7$ (Digimed, DM-20), and electric conductivity of $2.89 \mu \mathrm{S} \mathrm{cm}^{-1}$ (Digimed, DM-3), and it was soluble in all solvents (methanol, ethanol, acetone, ethyl acetate, chloroform, dichloromethane and benzene) except water (1:100 $\mathrm{mL})$.

The anacardic acid content of the CNSL sample was $52.8 \%$, as described by Agostini-Costa et al. (2004), measured spectrophotometrically by interpolating the absorbance of the sample against a standard curve for anacardic acid $(\mathrm{y}=0.1088+$ $\left.0.03102 \mathrm{x} ; \mathrm{r}^{2}=0.9762\right)$ based on a series of graded concentrations of this substance $(0,5 ; 1,0 ; 1,5 ; 2,0$; $2,5 \mathrm{mg} \mathrm{mL}{ }^{-1}$ ). It has a maximum UV-visible absorption between 280 and $320 \mathrm{~nm}$, corresponding to cardol and anacardic acid, respectively. Bands 3 and 4 , at longer wavelengths, probably correspond to methylcardol and cardanol (Figure 1).

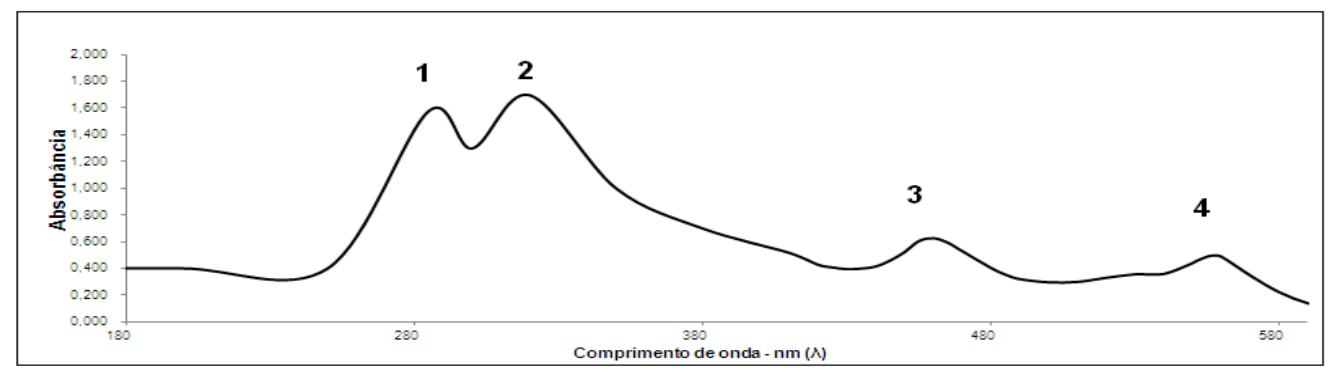

Figure 1. Spectrum of UV-visible absorption from Cashew Nut Shell Liquid. 1: absorption at $280 \mathrm{~nm}$ corresponds to cardol, 2: absorption at $320 \mathrm{~nm}$ corresponds to anacardic acid, 3 and 4 can not be identified accurately.

For the in vitro experiment, a stock solution of the CNSL sample was prepared, by diluting $0.5 \mathrm{~g}$ of the sample in $100 \mathrm{~mL}$ of water and adding $5 \mu \mathrm{mL}$ of dimethyl sulfoxide (DMSO).

Fungal activity was evaluated using the fungi $C$. gloeosporioides and L. theobromae, which cause anthracnose and fruit rot, respectively. The fungi were provided in culture medium by the Coleção de Culturas Maria Menezes da Universidade Federal Rural de Pernambuco (UFRPE) [the Maria Menezes Culture Collection of the Rural Federal University of Pernambuco], and stored in test tubes in laboratory refrigerators, having previously been grown on Petri dishes containing PDA (potato dextrose agar) culture medium and incubated until they reached maximum growth rate for the tests to be carried out.

Various concentrations of CNSL (20, 40, 80, 160 and $320 \mu \mathrm{g} \mathrm{mL}^{-1}$ ) were added to molten PDA (potato dextrose agar) in culture flasks $\left( \pm 45^{\circ} \mathrm{C}\right)$. As controls, plates containing only the PDA culture medium (pure control) and others containing PDA plus DMSO (the diluent for CNSL) were used. Ten-mL aliquots of agar medium already containing the various concentrations of CNSL were poured into Petri dishes. After solidification, in the center of the dish was placed a $5.0 \mathrm{~mm}$ disk of agar on which the fungus had been grown. The plates were then sealed and placed in a constant temperature chamber at a temperature of $22 \pm 2{ }^{\circ} \mathrm{C}$ and with a 12-hour light/dark cycle.
Evaluations took place daily, measuring mycelial growth based on the diameter $(\mathrm{cm})$ of the fungal colony in two opposite directions. The growth rate (TX) was determined from the results obtained, using the following formula:

\section{$T X=\frac{\text { Final Colony Diameter }}{\text { Number of days of incubation }}$}

Percentage values of growth rate of the pathogens in each treatment were used to calculate areas under the disease progress curves (AUDPCs) whose function is to assess the severity of disease, following the procedure proposed by Campbell; Madden (1990). A completely randomized design was used, with three repetitions per concentration.

In order to detect the presence and effect of possible volatile compounds, the previously described methodology was also used, but with no contact between the product and fungus. Only the concentration which caused the greatest inhibition in the in vitro tests was employed. Ten $\mathrm{mL}$ of PDA medium containing $320 \mu \mathrm{g} \mathrm{mL}^{-1} \mathrm{CNSL}$ was poured into a Petri dish. PDA (without CNSL) was also poured into the plate lid, onto which was then placed a $5.0 \mathrm{~mm}$ disk of agar that was colonized separately with the fungi. Analyses were performed as described for the in vitro methodology (BAJPAI; KANG, 2012).

Sporulation was evaluated by placing $10 \mathrm{ml}$ of sterile distilled water in Petri dishes on which the 
above tests had been carried out, and scraping the surface of the growth following a method adapted from Arboleda et al. (2014). Afterwards, the suspensions were filtered through gauze and samples deposited in a Neubauer chamber in order to count the number of spores.

Data on the inhibition of mycelial growth rate (TX), the areas under the disease progress curves (AUDPCs), and sporulation, were subjected to analysis of variance (ANOVA) and, when findings were significant, regression analyses were carried out with the help of Assistat software, Statistical Assistance, version 7.7 (SILVA, 2014).

For in vivo experiments, papaya fruits $(C$. papaya $\mathrm{L}$.) of the cultivar Golden, belonging to the Solo group, were used. They were bought in the Central de Abastecimento do Mato Grosso do Sul (CEASA/MS) [Mato Grosso do Sul Supply Center] in Campo Grande municipality, MS. The concentration used at this stage was the one most effective in the in vitro tests. A completely randomized design was used, including five repetitions of three fruits, totaling 15 fruits per treatment, following the methodology adapted by Maqbool et al. (2001).

The first treatment used was fruit immersion. To evaluate protective effects, 15 fruits were immersed in a solution of water plus the previously prepared stock solution, at a concentration of $320 \mu \mathrm{g} \mathrm{mL}^{-1}$ of CNSL. Two days later, the fungus was inoculated by depositing a fungus+mycelium disc over tears made in the fruits. The other treatment, to evaluate the curative effect, was carried out by first inoculating 15 fruits and then, after two days, immersing them in the same solution and concentration of CNSL. One control used fruits that had not been inoculated or treated with water and the second used fruits that had been inoculated and treated with water. The fruits were stored on trays sealed in plastic bags for 13 days, and readings were taken every two days, beginning on the fifth day after starting the test, measuring pathogen growth based on the diameters of the fungal colonies in centimeters, in opposite directions.

The daily growth rates (TX) and the areas under the AUDPCs were determined as described above for the in vitro experiments.

The data were subjected to analysis of variance (ANOVA) and, when significant, means were compared using Tukey's test $(p \leq 0.05)$, with the help of Assistat software.

\section{RESULTS AND DISCUSSION}

The in vitro tests resulted in significant inhibition of the mycelial growth of $C$. gloeosporioides and L. theobromae (Tables 1 and $2)$. Regression analysis indicated that the data for daily growth rates and areas below the disease progress curve fitted decreasing or quadratic linear equations, and the values of these parameters tended to decrease as the concentration of CNSL was increased. The best results were observed at a concentration of $320 \mu \mathrm{g} \mathrm{mL}{ }^{-1}$. There were no significant differences between the pure control, containing only the culture medium, and the DMSO control.

Table 1. Mean values of mycelial growth rate and area under the disease progress curve in antifungal activity in vitro assays of different concentrations of Cashew Nut Shell Liquid on Colletotrichum gloeosporioides. Campo Grande, MS, 2014.

\begin{tabular}{|c|c|c|}
\hline $\begin{array}{l}\text { CNSL concentration } \\
\left(\mu \mathrm{g} \mathrm{mL}^{-1}\right)\end{array}$ & TX $\left(\mathbf{c m ~ d a y}{ }^{-1}\right)$ & AUDPC \\
\hline 0 & 0.42 & 583.33 \\
\hline 20 & 0.42 & 573.18 \\
\hline 40 & 0.42 & 585.68 \\
\hline 80 & 0.40 & 572.92 \\
\hline 160 & 0.38 & 575.00 \\
\hline 320 & 0.35 & 518.75 \\
\hline LSD & 0.013 & 37.620 \\
\hline F Test & $37.09 * *(1)$ & $9.54 *^{(2}$ \\
\hline $\mathrm{CV}(\%)$ & 1.99 & 2.31 \\
\hline
\end{tabular}

The aliphatic chain of CNSL has both hydrophobic (apolar) and hydrophilic (polar) groups. This facilitates the permeation of microorganisms through the membrane of bacterial cell walls (lipoprotein 
membrane); the microorganisms flow through the lipid bilayer with the apolar group, affecting permeability, and once within the cell, the polar groups can act on the amino acid residues of proteins, inactivating them (PEETLA, 2013). Dix (1995) states in his book Fungal Ecology that substances containing phenol groups have fungitoxic effects because they inactivate enzymes related to energy production and the synthesis of basic metabolites. All of the components of CNSL are phenolic lipids. Therefore, CNSL's entrance into the intracellular environment is facilitated by the formation of chains and, once in the intracellular environment, its phenol groups work to inactivate enzymes of energy synthesis, hence possessing fungitoxic potential.

Table 2. Mean values of mycelial growth rate and area under the disease progress curve in antifungal activity in vitro assays of different concentrations of Cashew Nut Shell Liquid on Lasiodiplodia theobromae. Campo Grande, MS, 2014.

\begin{tabular}{lcc}
\hline $\begin{array}{l}\text { LCC concentration } \\
\left(\boldsymbol{\mu} \mathbf{~} \mathbf{~ m L}^{-1}\right)\end{array}$ & TX $\left(\mathbf{c m ~ \mathbf { ~ d a y } ^ { - 1 } )}\right.$ & AUDPC \\
\hline 0 & 1.2 & 359.60 \\
20 & 1.2 & 353.13 \\
40 & 1.2 & 359.96 \\
80 & 1.1 & 279.56 \\
160 & 1.0 & 271.53 \\
320 & 0.4 & 53.70 \\
\hline LSD & 0.166 & 79.433 \\
F Test & $327.40^{* *}(1)$ & $674.75^{* *}(2)$ \\
\hline CV $(\%)$ & 2.93 & 2.80 \\
\hline TX: mycelial growth rate; AUDPC: area under the disease progress curve; LSD: least significant difference; CV: coefficient of \\
variation. *: significant $(\mathrm{F}$ test, $p \leq 0.05) ; * *$ significant $(\mathrm{F}$ test, $p \leq 0.01) .{ }^{(1)} \mathrm{y}=1.206+0.000269 \mathrm{x}-0.00000859 \mathrm{x}^{2}\left(\mathrm{R}^{2}=0.99\right) ;{ }^{(2)} \mathrm{y}=$
\end{tabular}
$359.247-0.389 x-0.002 x^{2}\left(R^{2}=0.97\right)$.

Spores were counted in the in vitro experiments and, for both fungi, a reduction in the number of spores was observed as the concentration of CNSL increased (Figures 2 and 3).

The reduction in nutrients for microorganisms due to the activities of phenolic components results in a decrease in the production of their reproductive structures (OLIVEIRA, 2014). Agrios (2004) emphasizes the importance of a decrease in the sporulation of fungal pathogens in the control of disease, because the area of dissemination thus diminishes, along with the emergence of new disease outbreaks and growth of the pathogen in the soil via spores.

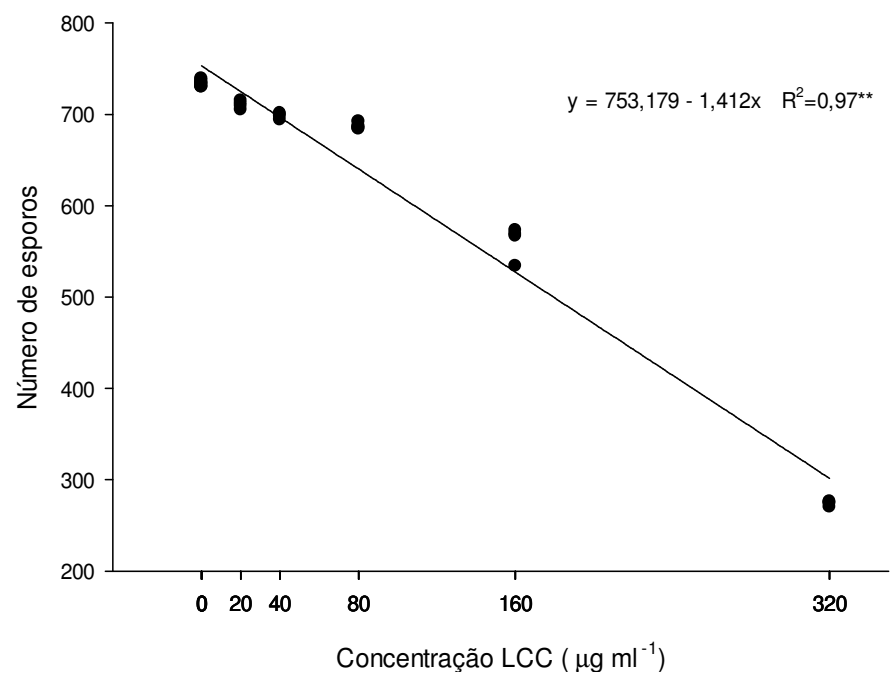

Figure 2. Number of spores of Colletotrichum gloeosporioides on different concentrations of Cashew Nut Shell Liquid in in vitro assays. Campo Grande, MS, 2014.

A test was conducted to determine if volatile components caused the inhibition by CNSL at $320 \mu \mathrm{g} \mathrm{mL}^{-1}$. It was found that in the absence of direct contact between the fungus and the CNSL 
there was no reduction in fungal growth, demonstrating that its inhibitory effect was not due

to volatile compounds (Figures 4 and 5).

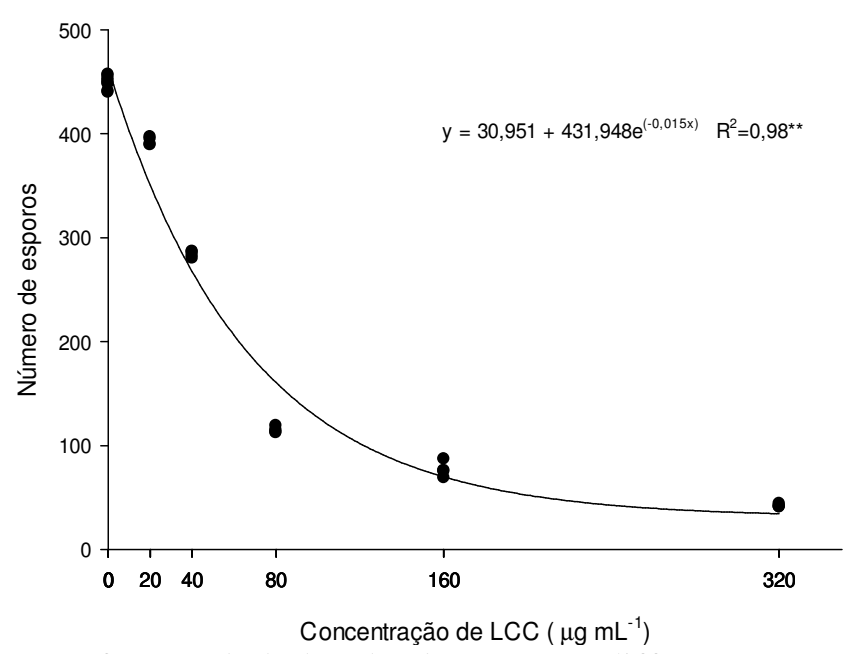

Figure 3. Number of spores of Lasiodiplodia theobromae on different concentrations of Cashew Nut Shell Liquid in in vitro assays. Campo Grande, MS, 2014.

To determine the possible agricultural applicability of a product it is important to determine if its inhibitory effects are due to the volatility of any of its components, as volatile products should be used in closed spaces, such as cold storage vessels or grain storage containers, while non-volatile products can be used in open spaces as the product does not have to create a microenvironment.

The characteristics of vegetable oils are mainly related to the size of their carbon chains and the extent of their saturation, which alters their molecular weights. The shorter the carbon chain and the greater the number of substitutions, the lower the melting point (ASIF, 2011).

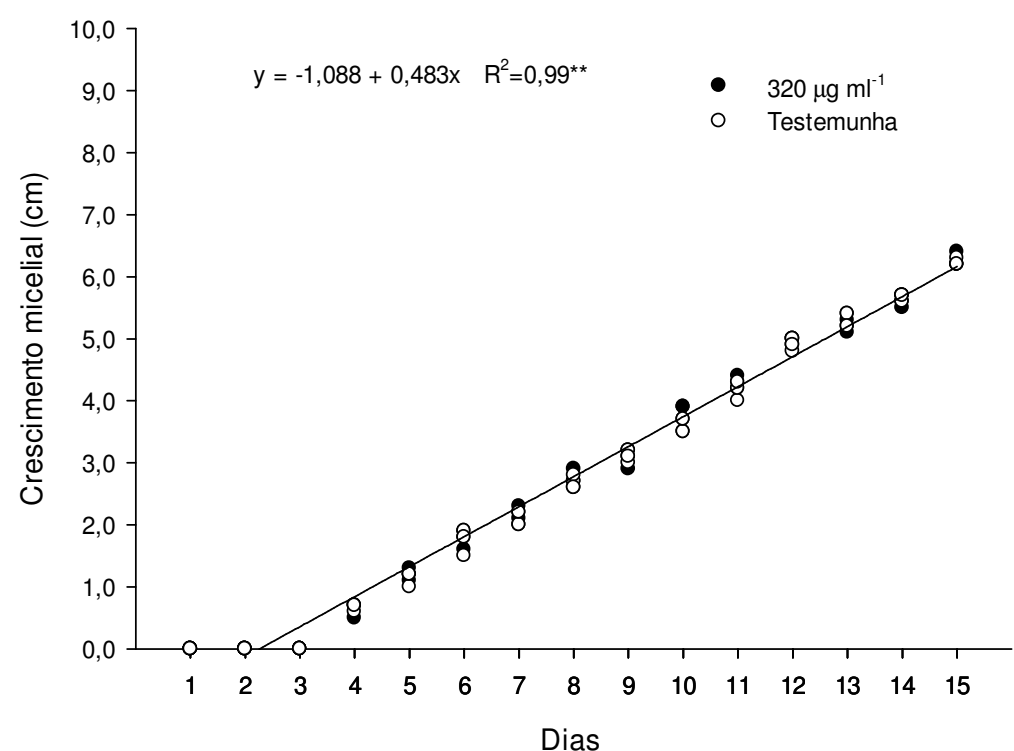

Figure 4. Mycelial growth of Colletotrichum gloeosporioides in in vitro assays to evaluate the action of the volatile compounds of Cashew Nut Shell Liquid. Campo Grande, MS, 2014.

The substances contained in the sample we employed have long lipid chains formed of 15 carbons and are thus unsaturated alkylphenols
(ANDRADE et al., 2010) and have molecular weights that do not allow for their volatilization. 
The in vivo test showed that protective treatment was more effective than curative treatment in terms of the reduction of both daily growth rate and the area under the disease progress curve for $C$. gloeosporioides, while the curative treatment was more effective than the protective treatment for $L$. theobromae (Tables 3 and 4). However, both treatments were effective compared to the controls.

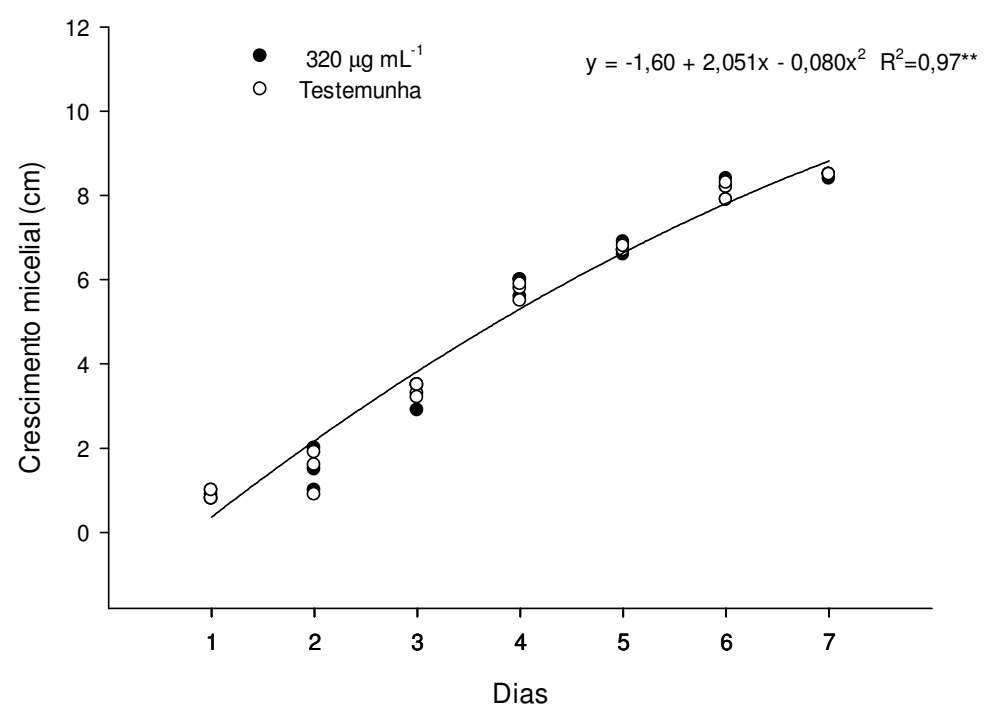

Figure 5. Mycelial growth of Lasiodiplodia theobromae in in vitro assays to evaluate the action of the volatile compounds of Cashew Nut Shell Liquid. Campo Grande, MS, 2014.

It is possible that the protective treatment was more effective than the curative treatment for C. gloeosporioides because this fungus tends to cause a rapidly developing infection. After contact with conidia or mycelia, hyphae penetrate the lumen of the host cell through the cuticle. These intracellular hyphae are biotrophic, killing the host tissue and causing necrotic lesions characteristic of anthracnose disease (SOLTANI, 2014). Therefore, pre-treatment, i.e. before the onset of the infection, may be more efficient in treating a rapidly developing infection which causes severe damage to the host.

Table 3. Mean values of mycelial growth rate and area under the disease progress curve in antifungal activity in vitro assays of Cashew Nut Shell Liquid on Colletotrichum gloeosporioides in papaya fruits. Campo Grande, MS, 2014.

\begin{tabular}{lcc}
\hline Treatments & TX $\left(\mathbf{c m ~ d a y}^{-1}\right)$ & AUDPC \\
\hline CTNI & $0.00 \mathrm{~d}$ & $0.00 \mathrm{~d}$ \\
ICT & $0.44 \mathrm{a}$ & $1.85 \mathrm{a}$ \\
Curative & $0.28 \mathrm{~b}$ & $0.72 \mathrm{~b}$ \\
Protective & $0.20 \mathrm{c}$ & $0.30 \mathrm{c}$ \\
\hline LSD & 0.007 & 0.052 \\
F Test & $12907.30^{* *}$ & $4336.08^{* *}$ \\
\hline CV $(\%)$ & 1.58 & 3.84 \\
\hline
\end{tabular}

TX: mycelial growth rate; AUDPC: area under the disease progress curve; CTNI: control treatment not inoculated; ICT: inoculated control treatment; LSD: least significant difference; CV: coefficient of variation. Means followed by the same letter in the column do not differ (Tukey test, $p \leq 0.01$ ). **: significant (F test, $p \leq 0.01$ ).

Curative treatment was more effective in the case of L. theobromae. According to Balaji (2013), in his research into fungi with bioremediation potential, L. theobromae has bioremediation potential because of its rapid growth rate and ability to absorb various substances present in the environment.
As explained earlier, CNSL is a phenolic compound which inactivates enzymes producing energy for the pathogen. Curative treatment may have appeared more effective because when the fungus had emerged from its latent state it faced an increased demand for energy, so that when CNSL was applied after two days, and this toxic substance 
was absorbed into the fungus, energy-supplying enzymes were inactivated. Thus, the fungus did not have sufficient nutrients to maintain its accelerated mycelial growth.

Table 4. Mean values of mycelial growth rate and area under the disease progress curve in antifungal activity in vitro assays of Cashew Nut Shell Liquid on Lasiodiplodia theobromae in papaya fruits. Campo Grande, MS, 2014.

\begin{tabular}{lcc}
\hline Treatments & TX $\left(\mathbf{c m}\right.$ day $\left.^{-1}\right)$ & AUDPC \\
\hline CTNI & $0.00 \mathrm{~d}$ & $0.00 \mathrm{~d}$ \\
ICT & $0.94 \mathrm{a}$ & $9.77 \mathrm{a}$ \\
Curative & $0.50 \mathrm{c}$ & $1.85 \mathrm{c}$ \\
Protective & $0.64 \mathrm{~b}$ & $4.23 \mathrm{~b}$ \\
\hline LSD & 0.03 & 0.58 \\
F Test & $2360.04^{* *}$ & $937.51^{* *}$ \\
\hline CV $(\%)$ & 3.47 & 7.82 \\
\hline
\end{tabular}

TX: mycelial growth rate; AUDPC: area under the disease progress curve; CTNI: control treatment not inoculated; ICT: inoculated control treatment; LSD: least significant difference; CV: coefficient of variation. Means followed by the same letter in the column do not differ (Tukey test, $p \leq 0.01$ ). **: significant (F test, $p \leq 0.01$ ).

\section{CONCLUSION}

The Cashew Nut Shell Liquid has antifungal potential for C. gloeosporioides and L. theobromae fungi.

\section{ACKNOWLEDGEMENTS}

The authors acknowledge the Fundação Manoel de Barros by their partnership.

RESUMO: O Líquido da Castanha de Caju é um lipídio fenólico extraído do fruto da Anacardium occidentale L. que demonstra ter potencial de uso biológico. A substituição dos agrotóxicos convencionais por produtos naturais vem aumentando devido aos impactos que o mau manejo pode acarretar a saudade humana e ao meio ambiente. Este trabalho objetivou avaliar o potencial fungicida deste produto frente aos fungos Colletotrichum gloesporioides e Lasiodiplodia theobromae por sua importância nos impactos negativos na produção frutífera. Foram realizados testes químicos e físicos para determinar o padrão da amostra como: $\mathrm{pH}$, condutividade elétrica, solubilidade e determinação do teor de ácido anacárdico na amostra. Para os ensaios biológicos foram realizados testes de inibição do crescimento micelial in vitro e em in vivo em frutos de mamões, determinação de compostos voláteis e inibição da produção de esporos. O LCC apresentou maior potencial fungicida no teste in vitro na concentração de $320 \mu \mathrm{g} \mathrm{mL}$ para ambos os fungos, nesta mesma concentração ocorreu a maior inibição da esporulação tanto para o C. gloesporioides quanto para o L. theobromae. No teste realizado in vivo ocorreu maior inibição para o fungo $C$. gloesporioides no tratamento protetor e para o fungo $L$. theobromae o tratamento curativo foi mais eficaz. Constatou-se que a substância com potencial fungicida não é volátil e a presença do patógeno altera os padrões químicos do fruto.

PALAVRAS-CHAVES: Controle alternativo. Ácido anacárdico. Carica papaya L..

\section{REFERENCES}

AGOSTINI-COSTA, T. S.; JALES, K. A.; GARRUTI, D. S.; PADILLA, V. A.; LIMA, J. B.; AGUIAR, M. J.; PAIVA, J. R. Teores de ácido anacárdico em pedúnculos de cajueiro Anacardium microcarpum e em oito clones de Anacardium occidentale disponíveis no Nordeste do Brasil. Ciência Rural, Santa Maria, v. 34, p. 1075-1080, 2004. Disponível em: http://www.scielo.br/pdf/\%0D/cr/v34n4/a17v34n4.pdf. Acesso em: 01 dez. 2016.

AGRIOS, G. N. Plant pathology. San Diego, California, USA. 2004. p. 90.

ANDRADE, C. H.; TROSSINI, G. H.; FERREIRA, E. I. Modelagem molecular no ensino de química farmacêutica. Revista Eletrônica de Farmácia, v. 7, n. 1, p. 23, 2010. https://doi.org/10.5216/ref.v7i1.9603 
ARBOLEDA, A.; MILLER, D.; CABOT. F.; TANEJA, M.; AGUILAR, M. C.; ALAWA, K.; AMESCUA. G.; YOO, S. H.; PAREL, J. M. Assessment of rose bengal versus ribo flavin photodynamic therapy for inhibition of fungal keratitis isolates. American Journal of Ophthalmology, New York, v. 158, p. 64-70, 2014. Disponível em: https://www.ncbi.nlm.nih.gov/pubmed/24792103. Acesso em: 01 dez. 2016.

ASIF, M. General chemistry, composition, identification and qualitative tests of fats or oils. Journal of Pharmaceutical Research and Opinion, Houston, v. 1:2, p. 52-64, 2011. Disponível em: http://innovativejournal.in/index.php/jpro/article/view/648. Acesso em: 01 dez. 2016.

BAJPAI, V. K; KANG, S. C. In vitro and in vivo inhibition of plant pathogenic fungi by essential oil and extracts of Magnolia liliflora Desr. Journal of Agricultural Science and Technology, Tehran Province, v. 14, p. 845-856, 2012. Disponível em:

http://jast.modares.ac.ir/article_4856_218fba469da0a3ae592decfddfeb617b.pdf. Acesso em: 01 dez. 2016.

BALAJI, V; ARULAZHAGAN, P; EBENEZER, P. Enzymatic bioremediation of polyaromatic hydrocarbons by fungal consortia enriched from petroleum contaminated soil and oil seeds. Journal of Environmental Biology, Lucknow, v. 35, p. 1-10, 2013. Disponível em:

http://search.proquest.com/openview/f2f71b77d6f3fc65d9115b5624fdac9a/1?pq-origsite=gscholar. Acesso em: 01 dez. 2016.

BAUTISTA-BANOS, S. B. Postharvest Decay: Control Strategies. Elsevier, London, UK. 2014.

CAMPBELL, C. L.; MADDEN, L. V. 1990. Introduction to plant disease epidemiology. Michigan, USA, 1990. $532 \mathrm{p}$.

DIX, N. J.; WEBSTER, J. Fungal Ecology. Chapman \& Hall, London, UK. 1995. 549 p.

https://doi.org/10.1007/978-94-011-0693-1

HALLENBECK, W. H; CUNNINGHAM-BURNS, K. M. Pesticides and Human Health. Springer Science \& Business, New York, USA. 2012. 166 p.

HERRERO-HERNÁNDEZ, E.; POSE-JUAN, E.; SÁNCHEZ-GONZÁLEZ, S.; RODRÍGUEZ-CRUZ, M. S.; SÁNCHEZ-MARTÍN, M. J. Temporal evaluation of the pollution by pesticides in natural surface and ground waters in a wine-growing region. Institute of Natural Resources and Agrobiology of Salamanca, Salamanca, p. 40-52, 2013. Disponível em: http://www.york.ac.uk/conferences/yorkpesticides2013/pdfs/074.pdf. Acesso em: 01 dez. 2016.

MAIA, F. J. N.; RIBEIRO, F. W. P.; RANGEL, J. H. G.; LOMONACO, D.; LUNA, F. M. T.; LIMA-NETO, P. DE; CORREIA, A. N.; MAZZETTO, S. E. Evaluation of antioxidant action by electrochemical and accelerated oxidation experiments of phenolic compounds derived from cashew nut shell liquid. Industrial Crops and Products, v. 67, p. 281-286, 2015. Disponível em:

http://www.sciencedirect.com/science/article/pii/S0926669015000369. Acesso em: 01 dez. 2016.

MAQBOOL, M.; ASGAR, A.; ALDERSON, P. G; MAHMUD, T. M. M; SIDDIQUI Y.; ZAHID, N. Postharvest application of gum arabic and essential oils for controlling anthracnose and quality of banana and papaya during cold storage. Postharvest Biology and Technology, v. 62, p. 71-76, 2011. Disponível em: http://www.sciencedirect.com/science/article/pii/S0925521411000949. Acesso em: 01 dez. 2016

MASON, R.; TENNEKES, H.; SÁNCHEZ-BAYO, F.; JEPSEN, P. U. Immune suppression by neonicotinoid insecticides at the root of global wildlife declines. Journal of Environmental Immunology and Toxicology, v. 1, n. 1, p. 3-12, 2013. https://doi.org/10.7178/jeit.1

OLIVEIRA, M. S.; BADIALE-FURLONG, E. Screening of antifungal and anti-mycotoxigenic activity of plant phenolic extracts. World Mycotoxin Journal, Wageningen, v. 1, p. 139-146, 2014. Disponível em: http://dx.doi.org/10.3920/WMJ2008.1006. Acesso em: 01 dez. 2016. 
PEETLA, C; VIJAYARAGHAVALU, S.; LABHASETWAR, V. Biophysics of cell membrane lipids in cancer drug resistance: Implications for drug transport and drug delivery with nanoparticles. Advanced Drug Delivery Reviews, Merck, v. 65, p. 1686-1698, 2013. Disponível em:

https://www.ncbi.nlm.nih.gov/pubmed/24055719. Acesso em: 01 dez. 2016.

SILVA, F. A. S.; AZEVEDO, C. A. V. ASSISTAT software: statistical assistance. Versão 7.7 beta. Campina Grande: DEAG-CTRN-UFCG, 2014.

SOLTANI, J.; HAGHIGHI, M. Y.; NAZERI, S. Light, temperature, and aging dependent vegetative growth and sporulation of Colletotrichum gloeosporioides on different culture media. Journal of Medicinal Plants Research, v. 8, n. 4, p. 208-216, 2014. https://doi.org/10.5897/JMPR12.1308 